\title{
PRILOZI
}

\author{
АНА ГАЛИЋ
}

\section{ХОРКХАЈМЕРОВА ПРЕДАВАњА О ДЕКАРТУ И ЛАЈБНИЦУ}

(Миодраг Живановић, Два предавања, Библиотека Епистеме, Зеница, Еидос, 2020., стр. 95)

Почетком 2020. године Декарту (Rene Descartes) и Удружење за филозофију и Готфриду Вилхелму Лајбницу друштвено-хуманистичка истраживања Еидос из Зенице (Gottfried Wilhelm Freiherr (baron) von Leibniz). Аутор објавило је најновији превод др наводи четири разлога за избор Миодрага Живановића, који се ова два филозофа. То су: 1. преводима бави већ деценијама, Декарт је утемељивач па тако можете читати и нововјековне мисли, а Лајбниц и професорове преводе дела апстрактног мишљења што је Фридриха Шилера (Friedrich представио учењем о монадама; Schiller) из 2005., или Карла 2. оба филозофа су Jacперса (Karl Jaspers) из 2011. рационалисти; 3. Декарт је године. Најновији превод саопштавао своју мисао посвећен је предавањима Макса директним говором, а Лајбниц Хоркхајмера (Max Horkheimer) која је држао 1927. године у Франкфурту, гдје је обухватио период од Галилеа Галилеја (Galileo Galilei) до Имануела Канта (Immanuel Kant). Аутор се одлучио за избор само два предавања, а ријеч је о предавањима посвећеним Ренеу метафорама, и 4. Декарт је био архитекта критике схоластике, а Лајбниц је критику окретао ка будућности.

Преводилац је књигу посветио Жељку Шкуљевићу, преминулом професору филозофије из Зенице. Поред два предавања о Декарту и 
Лајбницу, иза којих можемо наћи коментаре и напомене преводиоца, садржај књиге чини и уводна ријеч. У уводу сазнајемо да је преводилац користио конјуктив, али и разбијао предуге реченице које су садржавале партицип презента, те да је користио и архаизме. Оно најважније, а што је можда било и најтеже за превод, јесте кориштење метафора од стране Хоркхајмера, што је преводилац означио са „глаголом језика“, оним што тај језик покреће. Кључне појмове попут повијест, историја, знаност, наука, стварност и збиља преводилац је у складу са садржинским разликама поштовао у овом преводу. Лајбницово предавање остаје непреведено до самог краја - остало је пар страница које би се могле додати, а разлог je кратки запис на који је преводилац наишао те га је инспирисао - податак да у једном дијелу Индије везиље имају обичај да на крају свог рада остављају једну фигуру незавршену. Разлог оваквог чина јесте непостизање савршенства, на чије право имају само богови.
Прво предавање започиње помињањем Декарта заједно са Галилејем и Томасом Хобсом (Thomas Hobbes), као филозофа који је заслужан за профилисање нове механике. Посматран као новатор који је окренут ка будућности, списи су му били забрањени у протестантској Холандији и у католичком свијету, међутим сам Декарт је писао да „нема цијене да би објавио иједан спис у којем би се цркви било шта замјерило и најмањом ријечју“. Из живота сазнајемо да је као младић тада примио најбоље образовање, у језуитској школи у Ла Флечу (La Fleche), а да је онда прешао у Париз. Волонтира у холандској војсци од 1618. године и тада се повлачи у осаму како би студирао математику и филозофију. Године 1629. се враћа у Холандију, одмакавши се од борби против Хугенота, грађанског рата који је тада харао по Француској. Наредних двадесет година мијењао је адресе боравка 13 пута. Његово главно дјело „Принципи филозофије“ заједно са „Расправом о методи“ и „Диоптриком“ објављују се 1637. године у Холандији. 
„Медитације о првој филозофији“ излазе из штампе 1641. године. Декарт је скончао у Шведској, на позив принцезе Елизабет, од прехладе. Приликом напуштања језуитске школе Декарт је схватио да је потребно раздвојити теологију од механике, те се окреће поступку методске сумње. Рјешење ове сумње јесте спознаја егзистенције, односно свога постојања и тако Декарт долази до чврсте тачке у својој сумњи. То што мислимо и док сумњамо јесте доказ наше егзистенције, а знање које се при том спознаје мора задовољити два критерија - јасност и разговијетност. Декарт се водио разумном логиком до сада, односно у својим знаности посвећеним радовима, да би исту ту јасност и разговјетност примјењивао на доказ о постојању Бога, те објашњењу заблуда и зла које долази само преко човјека, тј. из његове хипофизе. Хипофиза јесте мјесто у којем се налази мислећа супстанца сваког човјека и уколико настане помућење, присуствујемо афектима, којих има шест: чуђење, жудња, мржња, љубав, веселост и невеселост. Декарт на овај начин разара материјалистичко схватање. Под материјалистичким се мисли на материјалност природних знаности, а када говоримо о картезијанској филозофији рећи ћемо да је то рационализам. Након што је представио основне црте Декартове филозофије, Хоркхајмер се пита због чега и дан-данас влада велики интерес за Декартов покушај сумње и за рјешење. Разлог је јасан: „Теорија сазнања јесте покушај апсолутног важења владајућег погледа на свијет, кроз повратак на апсолутно важење у свијести појединца. Стога, имамо непрестана тражења и расправљања због 'јасног и разговјетног' сазнања."1

Након коментара и напомена преводиоца читамо предавање о Лајбницу. Преводиоцу иде на руку избор другог филозофа, јер већ на почетку свога предавања Хоркајмер говори о Лајбницовом преузимању одређених картезијанских проблема. Лајбниц је био метафизичар, утемељен у природној знаности

1 Живановић, М. (2020) Два предавања, Зеница: Еидос (Библиотека Епистеме), 45. страна. 
и математици и значајан је по обједињавању цјелине знанствених увида. Метафизика коју је и сам Лајбниц користио служила се схоластичким апаратом, уз њено истовремено материјално пражњење, али и поред тога, Лајбниц је владао укупним образовањем времена у којем је живио као и знањем сваке знаности појединачно, те је важио и за сјајног математичара, физичара, дипломату и политичара религије. Лајбниц врло рано ступа у државну службу, у Мајнцу (Mainz), са 24 године, да би већ двије године касније кренуо у прва дипломатска путовања и врло брзо доспио у средишта свих великих друштвених промјена (пријатељ војводе Јохана фон Брауншвајга (Johann von Braunschweig); угледан гост на браденбуршком двору...). Од његових дјела треба споменути само она сабрана у 40 свезака, а већу пажњу ће посветити супстанцији, односно душевноживућем јединству, психичком индивидууму. Оваквих индивидуума има бесконачно и они припадају не само човјеку, него и животињама, биљкама, a такође и анорганском свијету и именује их монадама. Монаде су за Лајбница недјељиви, непросторни, неуништиви центри снаге психичког и постоје на два начина: као једноставне монаде и као душе. У најкраћем, ове најједноставније монаде су нејасне и несвјесне, непраћене мишљењем, а душе, напротив, имају свијест и мишљење (при чему људске душе имају Јасвијест и имају даљну егзистенцију и након смрти организма). Убрзо долазимо и до ноторног извода из Лајбницовог учења, а тај је да монаде немају прозора и до њихове престабилиране хармоније, а затим и до Хоркхајмеровог избора низа цитата којима покушава да одгонетне односе међу монадама и да дефинише збиљност код Лајбница. Оно повијесно у новијој филозофији јесте Лајбницово постављање активитета у монадски индивидуум, не у Богу, као што је чињено до тада. На крају је Хоркхајмер, за разлику од осталих интерпретатора који то раде на почетку, поменуо и спознајну теорију само Лајбница. Историјска заслуга Лајбница била би у његовом утврђивању основног задатка знаности - просвјећи- 
вања разума, не уско у виду критичке теорије, него и начина теорије, него у додјељивању на који Макс Хоркајмер ваљано вриједности, од праксиса, приступа најприје животу и односно у давању улоге сазнању биографији самих филозофа, као претпоставке за чињење, па њиховом цјелокупном опусу, а ce c пуним правом може на крају и њиховим филозоозначити и претечом просвјети- фским проблемима. Неријетко тељства. Друго предавање, како ћемо у изучавању историје смо поменули, прекида се у пола филозофије наићи на пропусте у реченице и након превода наведеним ставкама када је у читамо коментаре и напомене питању представљање најважнипроводиоца. јих имена у филозофији, а кроз

Мало је оних који нису чули овај превод ћемо стећи за Хоркхајмера и уопште квалитетан увид најприје као критичку теорију друштва. Ова они који се подучавају, а онда и предавања ће додатно заинтере- као они који ће подучавати. совати љубитеље не само 